\title{
PROFESSIONALIZATION FOR GRADUATE EMPLOYABILITY IN CAMEROON HIGHER EDUCATION: OLD WINE IN NEW WINESKINS?
}

\author{
Theresia Bilola \\ $\mathrm{PhD}$ \\ Doctor of Social Sciences, Option: Higher Education Policies \\ University of Turku, Finland \\ therriewhite@yahoo.com \\ ORCID ID 0000-0003-2813-533X
}

\author{
Doh Pascal \\ $\mathrm{PhD}$ \\ M.Phil/PhD in Higher Education Management and Governance \\ Lecturer of Higher Education Management and Governance \& Consultant \\ Higher Education Group, University of Tampere/HECADEV Consulting, Finland \\ Pascal.Doh@hecadev.com,dvcacademics@yahoo.com \\ ORCID ID 0000-0001-5884-2153
}

\section{ABSTRACT}

One issue to which higher education (HE) is increasingly expected to respond is graduate employability. In addition to its traditional missions, Cameroon HE is expected to pursue priority objectives. At independence, Cameroon HE was to train indigenes to replace expatriates in the state administration. However, the saturation of the state machinery obliged reforms and modified objectives. In a study including interviewees from the ministry of higher education and one state university, 'professionalization for employability' was identified as one of such objectives. The respondents were chosen on the basis of relevance to the topic, availability and willingness to respond. We discuss the origins and rationale of professionalization at independence and after the 1993 reforms. A peculiarity of professionalization is its articulation as a new 'objective' in universities. Using the Newmanian and the Market-Model perspectives, we argue that the novelty is in the attention, type of stakeholders and approaches and not in professionalization itself. It was noticed that some academics do not agree that universities should be concerned with employability of graduates. This is due to the belief in education for its own sake without utilitarian motives as well as uncertainty about the capacity of the national labour market. Even though the efforts have addressed both the supply and demand side of the products of HE, the supply side is insufficiently addressed. We conclude that professionalization; in the way it is currently being addressed cannot enhance graduate employment and relevance of university education to the job market as intended.

Keywords: Cameroon; graduate employability; higher education; professionalization; reform.

\section{INTRODUCTION}

The data was obtained through semi-structured face-to-face interviews at the Cameron ministry of higher education and the University of Buea in 2011-2012. The 
interviewees were academics who are either partially (held administrative positions) or fully involved in university teaching. The respondents were chosen on the basis of relevance to the topic, availability and willingness to respond. Another basis was to capture both the perspective at the system level (ministry) and at the institutional level. In addition to the interviews, policy documents and other government documents this article employs other data and analysis on professionalization by Doh (Doh P. S., 2012). The analysis hinges on the seeming shift from a predominantly Newmanian perception of higher education towards a Market-model.

\section{CONCEPTUALIZING PROFESSIONALIZATION IN HIGHER EDUCATION}

There is worldwide concern that existing higher education programmes are not producing graduates with the kind of professional skills which they need in order to be successful in their careers (De la Harpe, B., Radloff, A., Wyber, J., 2000). On the basis of this concern, employability is the predominant purpose for professionalization. There is a challenge of the traditional conception of university education and the interest in employability is driven by human capital theories of economic performance (Schultz T., 1961; Becker G., 1994; Blaug M., 1965; Kivinen O., Nurmi, 2014: p. 1). What counts is no longer what is known but what can be done with what is known. Knowledge has to be put to work, seen to work and be in work (Symes, McIntyre, 2000). Higher education systems are therefore steered to emphasize on the employability of graduates. Professionalization involves higher education actively preparing the student for employment. Employability is the capability of the higher education graduate to gain and maintain initial employment and to obtain new employment if needed (Hillage, Pollard, 1998). According to Yorke (Yorke M., 2001); Knight and Yorke (Yorke M., Knight P., 2000), the educational conception of employability relates to the ability to tackle "graduate" jobs and; the ability of the graduate to get (any) job. The former implies getting a job that is equal to the qualification acquired and the latter is employment without consideration of the qualification. In the Cameroonian context professionalization is defined as a strategy to adapt curriculum and its related technologies (teaching and learning) to socio-professional needs and applicability (Doh, 2012: p. 143). However, the viewpoints on professionalization as a premise of universities have been varied.

\section{DIFFERENT SIDES IN THE PROFESSIONALIZATION DEBATE}

In this section we summarize the views of the university as an institution that should or should not be involved in professionalization. Although from different perspectives, professionalization has been debated since the beginning of higher education (HE) systems (Robbins, 1963; Leroux, 2014: p. 90). According to Leroux (ibid) there are two perspectives. One perspective (which has been expressed in two different ways) sees higher education for knowledge creation and dissemination (Renaut, 1995). Within this perspective is the Nermanian approach which believes in higher education for "neutral" or general knowledge which in itself is sufficient (ibid). On the other hand is the scientific or Humboldtian perspective where priority should be given to HE for science and by science. The convergence between the Newmanian and Humboldtian 
perspective is that they both stand on the premise that higher education is not meant to impart professional skills which can be directly used in the workplace, a mission intended for professional schools.

The "Market Model" of the professionalization debate which originated from Harvard University (Engell, Dangerfield, 1998) was inspired by the Humboldtian model but the difference is that knowledge and research are not viewed as ends in themselves but as channels for development in all aspects of socio-economic life (Leroux, 2014: p. 91). Leroux further opines that professionalization in this view does not detract from one key HE mission to provide general education. Hence professional training will always have an academic component but this will be insufficient in itself. Professional training therefore has the additional role of immersing the student into the "real" professional world. Engell and Dangerfield's (Engell J., Dangerfield A., 1998) "market model" holds that market signals are monitored and translated into new curricula and programs. Proponents of the model define a new logic in which "students tend to be seen as consumers rather than members of a campus community (and) the major responsibility for managers is to read the market...and attempt to reposition accordingly" (Gumport, 2002: p. 55). The novelty is the raw power that money has over higher education activities (Clark, 1998; Marginson, Considine, 2000; Kirp, 2003: p. 3). It is implied that higher education (HE) should help its graduates to find their place in the socio-professional world. The market model relates to the "market" angle of Clark's (1983) coordination triangle redefined as the "society" (Cloete, Maasen, 2002: p. 23-25) or the "stakeholder society" (Neave, 2002). In essence the control of how higher education behaves is no longer determined within higher education institutions but by the market that governs them (Geiger, 2004: p. 261). Due to the increased importance of the knowledge economy (Kivinen, Nurmi, 2014: p. 1), the market-model HE is prolific in national and international higher education policy. In articulating the functions and mission of HE, the UNESCO Declaration particularly affirms contributing to the development of the society as a whole (UNESCO, 1998, Art. 1 a) using courses and content continuously tailored to present and future societal needs. This anticipatory role defines relevance as the fit between what the society expects of $\mathrm{HE}$ and what it does (Art. 6 a). Article 7 recommends strengthening the links between HE and the world of work. These links include apprenticeship opportunities; exchange of personnel; joint development, delivery and assessment of curricula and; systematic consideration of trends in the labour market. Evidence of the market model perspective can be found in the Cameroon's Growth and Employment Strategy Paper (Growth and Employment Strategy Paper (GESP) for 2010-2020, Cameroon: Government of Cameroon., 2010: p. 49) with statements like "university training with a professional focus....encouraging professional training and prioritizing the satisfaction of local needs"; [higher education] will monitor the professional integration of graduates, validate professional achievements and certify professional competences (90). The GESP (GESP, 2010: p. 50) and the Education sector strategy (Education Sector Strategic Plan, 2006: p. 58) also attribute high unemployment to the professional training which is not tailored to the needs of companies. By implication, professional training will be tailored to these needs as recommended by the market-model. As stated by Kivinen and Nurmi (Kivinen O., Nurmi J. 2014: p. 1) higher education is expected to produce marketable professional competencies. 


\section{THE CAMEROON HIGHER EDUCATION SYSTEM FROM INDEPENDENCE TO DATE}

Higher education (HE) in Cameroon began with the Federal university in 1962 to the University of Yaounde in 1974. For many years, the university was not directly involved in professional training despite the articulation in policy papers. This is due to the French styled (Leroux, 2014: p. 91; Ngwana, 2001: p. 2) higher education where universities focus on classic disciplines while professional HE is predominantly the premise of specialised institutions or grandes ecoles (Tambo, 2003: p. 18; Ngwana, 2001: p. 2). The pre-1993 Cameroonian university could be more likened to the Newmanian and Humboldtian models. Training was focused on obtaining a higher education degree for its own sake because employment was guaranteed. According to Njeuma et al. (Njeuma, D., 1999: p. 2) and corroborated by the interviews, the period from 1962-1967 was for creation of general education structures, and the building of professional and technological schools happened after 1967. The saturation of the public service, increasing graduate unemployment and exponential growth in student enrolment necessitated attention to the professionalization embodied in the 1993 reforms and subsequent policy reforms. Policy documents, public speeches and most respondents for this research hold that professionalization is new or recent in Cameroon higher education. For instance, addressing the youths on the $49^{\text {th }}$ youth day, the Cameroonian president alluded to "the relatively recent adoption of professionalization of education in Cameroon". Professionalization as a premise of higher education is not new and was already articulated a few years after independence. As early as 1974 the session of the National Council for Higher Education and Scientific Research recommended the enhancement of professionalization (Sup Infos September, 2011: p. 38) and it was resolved that university studies should be reorganized to reflect the needs of the country. The approach was to create a university of technology to train technicians to support the nation's economic progress and; the establishment of selective post-graduate programs pursuing research to solve national problems (Njeuma et al., 1999: p. 4). The period from 1962-1992 was characterized by the progressive involvement of higher education in technological and professional training (Sup Infos, 2011: p. 9). The efforts to respond to national and job market needs is in line with monitoring market signals and translating them into new curricula and programs. Following broad reforms in 1993 it has been a particular focus of the university to train highly skilled professionals. New ways of doing things have been instated to fit the professionalization agenda and commitments to professionalizing efforts are rife. For instance the Bologna Process was adopted in 2008 aimed to render degrees nationally and internationally readable. New programs and revised curriculums have also been initiated. The GESP (GESP, 2010: p. 76) states that professionalization will be more refined. In the 2000s, one strategic objective of higher education in Cameroon is "to professionalize and enhance graduate employability" (Samfoga Doh, 2015). This objective is being pursued by increasing the professional content of traditional programs, increasing the professional and technical study options, revising or renewing curricula and linking university education to the professional world (Samfoga Doh, 2015).

Today, the Cameroon higher education system is composed of eight (8) state owned universities (State universities are owned and predominantly 
funded by the state) and a private sector of over 164 institutions (as at January 2015; portal of private higher education institutions in Cameroon [Electronic resource]). Cameroon also hosts the sub-regional virtual university and one national virtual university. Policy is determined and instituted by the ministry of higher education. The educational system owes its origins to its last European colonial background as a former French and British Colony. Consequently, the system is dominantly a hybrid of the French (80\%) and British (20\%) educational systems and thus, a "bicultural" system of education (Doh, 2007). The predominantly French model higher education (Leroux, 2014: p. 91) implies that that professional higher education was seen as the domain of highly selective independent and specialized institutions. After independence, these institutions focused on magistracy, international relations, teaching and health. A major difference between these schools and full-fledged universities is in the admission process. For the specialized schools, admissions are highly competitive and based on entrance exams while university admission was relatively open especially when there was only one university and the state needed to motivate people to enroll (Njeuma, et al., 1999: p. 2). The perception of grandes ecoles for professional programs and universities for classic disciplines is one reason why the increasing focus of professionalization of universities is seen as "new". In addition to the universities and specialized institutions, most private higher education institutions are oriented towards professional and vocational training than traditional disciplines. The focus of the current paper is state higher education institutions.

\section{EVOLUTION OF PROFESSIONALIZATION IN CAMEROONIAN HIGHER EDUCATION}

From its inception, the objectives of Cameroon higher education were linked to the vision of a newly independent country seeking to develop locally educated human resources to manage its own affairs (Njeuma et al., 1999: p. 20). All efforts were to prepare graduates for immediate integration into the public service or government-owned corporations like the national radio and television corporation (Njeuma et al., 1999: p. 9). During the 1960s and 1970s university professional training was primarily in health, literary studies, agriculture and management (Sup Infos September, 2011: p. 33). Alongside the National institute for University Studies created in 1961, professional programs were developed through the schools of administration, agriculture and the military academy (Njeuma et al., 1999: p. 2). An international (inter-African) dimension was added to the University of Yaounde with the creation of the Yaounde International School of Journalism and the Institute of International Relations in 1970 and 1971 respectively. Njeuma et al. (ibid) states that the period from 1962-1967 was marked by the establishment of general education and after 1967, professional and technological schools were created. Structurally, Cameroon had two types of higher education institutionsfundamental education offered by the university and professional/technical education offered by specialized institutes or schools (Njeuma et al., 1993: p. 2). Some of these schools are still within the universities but operate independently. The respondents interviewed for the current study held that the motive to train students who can be employed out of the public sector was non-existent in the immediate years after independence. Some of the respondents believe that the 
focus on the public service was exaggerated to the detriment of establishing a higher education system that can train students who can be employable out of the public sector or be able to create jobs themselves. The exaggeration was seen in absence of tuition fees, free room and board as well as bursaries for university students who upon graduation expected immediate employment. Some scholars (Njeuma, et al., 1999; Ngwana, 1993; Doh, 2012) have observed that this was an error at the conception of Cameroon's higher education and most of the subsequent reforms have been focused on correcting this error. Due to the open admission policy in universities and stricter admission requirements for professional schools, the efforts at professional education were not producing enough graduates for government positions. It was clear that the there was a challenge to increase the number of students undergoing professional and technological training. The motivation with the generous student welfare system resulted in unprecedented growth in student numbers without a corresponding increase in infrastructure or teaching staff. The University of Yaounde which began with 529 students and 22 teachers in 1962 had expanded to 2500 students with 200 teachers in 1970 (Njeuma et al., 1999: p. 3). Even though it was built for 5000 students, the university enrolled 7091 students by 1976, 45,000 students in 1991 (Njeuma et al., 1999: p. 5) and approximately 166,000 students in 2010 (Sup Infos September, 2011: p. 9). As at 2011, the yearly increase in enrolment into state universities was estimated at 11 percent (Sup Infos, 2011: p. 11). However, the growth in the number of employers (who could employ degree holders) was not also commensurate with the number of university graduates. According to the Education Sector Strategic Plan (ESSP, 2006: p. 58), only 37 percent of these higher education graduates are conveniently integrated into the labour market.

The 1990s environment for reforms was set. There was a lone university concentrating on classic disciplines and some professional schools for a privileged few. It was soon realized that the lone university of Yaounde could not hold the exponential number of students knocking on the doors of higher education every year. In addition, the quality of teaching and learning conditions was deteriorating with success rates as low as 30 percent (Njeuma et al., 1999: p. 5; Konings, 2004: p. 290). It became evident that the government could not continue subsidising the basic infrastructure needed to handle the massive growth in the student population. This resulted in rapidly sinking educational standards (Mbembe, 1985; Ndongko, Tambo, 2000; Konings, 2002). As Konings (Konings P., 2004: p. 289) holds, it became common in Cameroon to hear people say that "there is a shortage of everything in our schools and universities except students". This malaise was evident in the severe decrease and irregularity of state funding for higher education (Njeuma et al., 1999: p. 5-8; Konings, 2004: p. 290; Sup Infos, 2011: p. 10). By the late 1980s and early 1990s the national economy was not faring well with brutal salary cuts and the 50 percent devaluation of the national currency. According to one respondent, the first signals were in 1983-1984 when the population growth rate exploded. The response from the government was the recruitment of 1000 higher education graduates and another 1500 a year later. The idea was to absorb all graduates but the population growth rate could not be matched with all the efforts and the economic crises began in 1984. Some state corporations were closed and employment stalled. This necessitated the question: are graduates relevant to the labour market? The government decided to undertake a major overhaul which was articulated in the 1993 reforms. 


\section{PROFESSIONALIZATION IN THE 1993 REFORMS}

The ministry for higher education was created in 1992 (Decree of 27th November 1992). The 1993 reforms are contained in a series of presidential decrees signed between April 1992 and January 1993 (Decree No. 93/026, Decree No. 93/027, Decree No. 93/034 and Decree $\mathrm{N}^{\circ}$ 92/074). According to Njeuma et al. (Njeuma et al., 1999: p. 9) the main goals of these reforms were: decongestion of the University of Yaoundé and; professionalization of university education in order to produce graduates who could be useful to the private sector and the country. The motive was directly utilitarian and addressing relevance. University education for its own sake was no longer primordial. Promoting the attractiveness of the local universities with generous student welfare provisions was no longer required. There were more than enough applicants, aspirants and graduates already. This stance was echoed by some interviewees who stated that the state could not/cannot continue to spend money on higher education without seeing the contribution to socio-economic development. Njeuma et al. (Njeuma et al., 1999: p. 9) holds that the 1993 reforms were to "make programs professional, adapted and responsive to the needs of the job marketprovide programs that would enable graduates find employment in the private sector as well as create employment". It was considered that graduates from the University of Yaounde did not receive the type of education required by a demanding private sector and professionalization became a key goal (Njeuma et al., 1999: p. 9). The curricula designed in the 1960s were inadequate for the 1990s demands of the private sector, market forces and the increasing tendency of the government towards retrenchment by down-sizing public service man power (Ngwana, 2001: p. 3). In consultation with other stakeholders, universities were required to define local market needs, involve professionals in the conception of programs and define admission and teaching requirements for professional programs. Prior to the reforms, professional schools/centres existed (agriculture, translation and interpretation, food technology, commerce, journalism, international relations and medicine). The novelty of the reforms was the introduction of professional programs within universities. For instance women and gender studies, accountancy, banking and finance, nursing, medical laboratory science, journalism and mass communication were introduced at the University of Buea. The earlier years of the 1993 reforms saw an apparent reduction in student-teacher ratio and increased infrastructure. However, a superficial look at the numbers clouds the actual situation that followed within a short period (Ngwana, 2001: p. 3; Njeuma et al., 1999: p. 17). Most of the new universities still face the same challenges that had necessitated the reforms. It is however difficult to assess the effects of professionalizing on the employability of graduates. At best the interviewees could only make vague statements about university graduates on the labour market. Statements like: “....our students perform very well in the job market"; "Really I will not lie. We cannot tell what becomes of them [university graduates]. It is not our task"; "We have an alumnus which is doing well but there is no coordinated effort or association for them"; If most of our students are retained [by employers], it means that the training was properly done."

\section{POST 1993 REFORMS: EXTENSIONS AND CONSOLIDATION OF PROFESSIONALIZATION}

After 1993, the major reform policies shaping the professionalization of higher education include: the Bologna Process (BP); the New University Governance 
policy; the 2001 law on the orientation of higher education in Cameroon; The Poverty Reduction Strategy Paper turned Growth Employment Strategy Paper; the Education Sector Strategy and the Global Reform of higher education launched by the 1999 UNESCO Conference in Budapest. According to the BUN (December 2008: p. 4), the ultimate aim of these reforms is to produce graduates who can succeed socially and economically in the globalized world, a world driven by a knowledge-based economy. This section discusses the professionalization of higher education with reference to these reforms The BP overlaps with the New University Governance policy which articulates emphasizing professionalism by expanding professional and technical education opportunities (Buea University Newsletter, 2008: p. 4; Sup Infos March 2011: p. 7).

Since 1993 professionalization has been articulated in every major higher education (HE) document, it is constantly articulated in public speeches by higher education and other government officials. For example the President's messages to the Youth in 2007: "various actions are envisaged or ongoing as part of a professionalization and diversification program"; 2011 "Regarding higher education, professionalization remains the watchword, without neglecting the extension of the LMD system"; 2012: "In fact, professionalization or training, as the case may be, is a prerequisite to resolving the problem of youth employment" 2014: "Our educational system at its different levels had already opted for professionalization. We will soon witness its impact, which you will find remarkable" and 2015: "....given the relatively recent adoption of professionalization of education.....its impact will definitely not be immediate. As observed by some respondents at the University of Buea and corroborated by policy documents, the success of professionalization is mainly hampered by the inability of the industries and private sector to match the demands of the HE professional training. These needs include support through internships, consultancy services and involvement in teaching (BUN, 2008: p. 6). According to the University-Industry Partnership Charter (MINESUP, 2010: p. 5), "the universities are assigned two additional missions: counseling and professional integration of students". One respondent from the ministry stated that the Cameroon HE at that time (Cameroon Prime Ministry, 2011) was approximately 250,000 students but the number of potential employers was very few. It was however asserted that the idea is not only to train the student to find a job but to able to create a job(s). The interviewees also stressed the quest for quality as relevance embodied in the professionalization objective. As one interview holds, the perspective of the professional world is expressed as:

Your theories at university are pretty good but we need someone who is ready for action-relevance with regards to the relation to professional practice. Behind all that there is employability because we realize that in reality professionalization by adapting to the socio-professional environment does not solve all the problems.

The role of the knowledge economy was equally seen to be at the root of the professionalization efforts in Cameroon. Most of the interviewees alluded to the importance of higher education in the country's goal of becoming emergent by 2035. This is in line with Leroux's (Leroux J-Yves., 2014: p. 91) assertion that higher education is not seen as an end itself but as a channel for all aspects of socioeconomic development. It was stated that the very foundation of higher education objectives is the country's development objectives. Professionalization is expected to improve employment and hence socio-economic development.

In addressing the employability of Cameroon graduates the concern of policy makers is more about ability to tackle graduate jobs than about the ability of 
the graduate to get a (any) job (Yorke, 2001; Knight, Yorke, 2000). For instance the president of the republic, states (in advocating professionalization) that many educated but unemployed youths resort to precarious options, unrelated to their training or qualification in order to eke out a living (PRC, 2015). Corroborating this assertion, some respondents hold that the attention to professionalization ensued from the increasing number of university graduates who resort to petty trading or street vending, discrediting all the investments in higher education (HE). One respondent related the employability by comparing the time it takes for graduates to get their first job: on average it takes 3-4years for graduates from traditional/classic disciplines and 1-2years for graduates from professional/ technological disciplines. According to the respondent, HE needs to produce graduates who rapidly get employed.

\section{FROM EDUCATING FOR THE STATE TO EDUCATION FOR THE “LABOUR MARKET": THE INCREASING PREDOMINANCE OF THE MARKET MODEL}

The professionalization of university education (HE) in Cameroon has increasingly moved from the Newmanian model towards the Market model. The shift is echoed in the Cameroonian president's 2015 youth day speech where he alludes to the long-time believe in continuously increasing access to education and the relatively recent adoption of professionalization. He further blames unemployment on the delay in directing higher education towards professionalization (Presidency of the Republic of Cameroon, 2015). Owing to the increased focus on economic development, the coordination and governance of the higher education system seems to be moving towards Clark's (Clark B. R., 1983) "market" angle and as perceived by Cloete and Maassen (Cloete N., Maassen P., 2002), towards the "society" angle, or the "stakeholder society" (Neave, 2002). It is however interesting to note that the changes have been more in policy and program transformation than in the student enrolment trends. Before the year 2010, less than 5 percent of students enrolled in professional or technological programs and the rest in classical programs (Doh, 2012: p. 144). Surprisingly, the objective to train more students in professional than classical disciplines is still in its infancy, more than a decade after the 1993 reforms. From the foregoing discussion, it is evident that professionalization was of concern in HE before 1993 but the difference lies in the perspective and approaches adopted. In the years following independence, the aim was to produce graduates who are quickly employable but the target was specific - the national labour market or state administrative machinery. Admissions into the professional institutions/programs were not only extremely competitive but were based on the actual openings for recruitment into the public service (Ngwana, 2003: p. 2). Unlike in the subsequent reforms, the need for relevance to the private sector and some "abstract" (national and international) labour market was inconsequential in the immediate years after independence. In addition, professionalization was addressed by providing selective professional training opportunities and not broadly professionalizing every aspect of university education. As earlier mentioned, the market model embodies: attention and adaptation to societal and job market demands; emphasizing and facilitating the employability of HE graduates; interaction with the world of work, graduate insertion and; usefulness of graduates to the society. Evidence of 
the market model is embodied in the Bologna process, which aims for a higher education that is attentive to societal needs (Sup Infos, 2011: p. 48). As evidence that professionalization has existed but needs to be more central, the GESP (GESP, 2010: p. 76) posits it will be more refined. Refining includes actions like developing professional and entrepreneurship and; strategizing employability and insertion of graduates into the job market. For instance, the support program for the technological and professional components of $\mathrm{HE}$ aims at 25-30 percent enrolments in these programs by 2015 (MINESUP, 2010).

Considering that the most important reason for professionalization is to have graduates to be easily inserted into the socio-professional world, it was necessary to find out how policy and practice address interactions between the university and socio-professional actors. According to respondents and policy documents, interactions are governed by agreements between both parties. One of such is the University-Industry Partnership Charter signed between the ministry of higher education and representatives of industries in 2010. In addition there are other regulations like the accreditation of every new program is based on proof of the involvement of socio-professional stakeholders in the design of the curriculum. In practice universities interact with socio-professional actors through student internships, university hosted business forums, research and teaching collaborations. However, some respondents held that these interactions are still at infancy and the full benefits are yet to be seen. There were also complaints about differences in perspectives between academics and business people and the effect on the growth of these interactions. The missing link in all the efforts was the very subject of professionalization-the student. There are limited provisions for the input of the students both during and after their studies at the university. This was blamed on the perception of students as immature and not ready to contribute. Notwithstanding, some respondents hold that the absence of information on the situation of university graduates in the labour market is a setback for the professionalization agenda. As one respondent stated "universities become like someone who puts meat in a mincer, turns the mincer, but does not care where the minced meat is going". One respondent acknowledged this loophole in the following statements:

We do not have a structured way of reaching into the employment world to really find out for ourselves about employment rates of our graduates. I think this is an area where will still need to invest. However, there are informal relations like the internships where we find that most students who go for internships are later retained as employees.

\section{CONCLUSIONS}

In the years following Cameroon's independence, professionalization was not particularly important because the supply side (job market) was already addressed. There was a state administration and its agencies which needed to be filled. The clearly defined "job market" was relatively predictable and controllable. For instance students trained in law proceeded to the school of magistracy and later were employed by the state. This explains why there was no need to focus on relevance in the way it is highlighted in the 1993 and other subsequent reforms. However, when this specific job market was saturated, an undefined, unpredictable and uncontrollable labour market was born. This imaginary labour market is 
mention in policy papers and speeches but the avenues for higher education to interact with and immerse their graduates into the market do not match the magnitude of changes that universities are making to render their graduates "professional". In fact most of the interview respondents expressed skepticism about whether professionalization is not just fuelling brain drain. There were questions about the means available to completely professionalize and on the readiness of the market. Students obtain professional training which makes them more attractive to the international labour market because the national market (especially the private sector) does not have sufficient potential to absorb the graduates. These graduates are forced to seek greener pasture out of the country after being professionally trained with the state's funds. The professionalization policy is not matched by an appropriately strong demand side (Doh, 2012: p. 186) agrees with Hartog (Hartog J., 2000) that this mismatch could reinforce the risk of over education (Reinert, 2007: p. 320-21) in Doh (Doh P. S., 2012: p. 186) argues that "...nations that address only the supply side of educated people end up educating for migration" and underemployment in the case of Cameroon. Interestingly, the migration of graduates was mentioned by several respondents as a measure of the quality of education received. For instance one respondent stated that graduates are useful, especially those from the technical disciplines. The respondent holds that evidence for the usefulness is evident in the fact that 40 percent of doctors trained in Yaounde go out of the country. Other respondents held that satisfaction is derived when many Cameroonian graduates can be able to find work abroad. The universities train as many students as possible so that some remain in the country. It was also stated that there are minimal and uncoordinated efforts to obtain information on how the graduates fare in the labour market. At best there were general estimations and weak links with some alumni associations. However, some respondents held that one reason for the lack of follow-up is the reluctance of academics to accept insertion into the job market as part of the university's mission. It was also attributed to the predominantly French culture which does not pay attention to relations with students after graduation. This reluctance is echoed by some respondents who hold that professionalization is borrowed and does not belong in higher education.

It can be concluded that professionalization has been in university education from its inception but the importance has increased over the years. The importance results from the changing international and national environment - changes in higher education (HE) is expected to do; changes in the socio-economic environments and consequences on the perceptions of university graduates; changes in theories on the usefulness of university training; funding challenges and population growth. The pursuit for professionalization in Cameroon HE is strongly motivated by the ability for the graduate to be employed, especially the ability to gain employment that correlates with the qualification obtained. This implies that the definition of employability in Cameroon HE is the ability of the graduate to secure a graduate job. Professionalization of higher education in Cameroon is not new as an objective but certain changes have rendered its articulation as new. These changes include accepting professionalization as the premise of universities too. This acceptance has led to increasing the number of university professional courses/programs; increasing the professional content of traditional programs and actively involving potential employers in the design, delivery and assessment of curricula. However the acceptance is not shared by all academics. Some hold that professionalization is a borrowed and has no place in higher education. There has 
been a shift in the perception of what higher education should do. The perception at independence was more Newmanian - the country needed people with university degrees and the professional content was not an issue. When the state agencies could no longer employ, the University became Market-Modelled and needed to respond to a stakeholder society with university degrees tailored to the demands of this market and stakeholders.

In order for the professionalization agenda to succeed, there is a need to assess its effects. The effects can be assessed from information on the employment of graduates with professional skills. If this is ignored then Cameroon may only train for labour markets out of its borders. In addition, there is a need for more opportunities for interactions between the university and the socio-professional world to build trust and facilitate collaboration. At the policy level there seems to be the need for a clear picture of who/what this national "labour market" is. From this picture, it will be easy to determine whether the labour market can absorb the graduates produced within the professionalization initiative. According to the respondents this had to be figured out before diving into the professionalization agenda. However there is still room for adjustments as the society and the university is constantly changing. The gap in this paper is the absence perspective of the so-called socio-professional environment to which the 'professionalized' graduates are directed. Notwithstanding, we present a starting point for research on the effectiveness of the professionalization policy in Cameroon universities.

\section{REFERENCES}

1. Becker, G. (1994). Human Capital: A theoretical and Empirical Analysis, with special reference to Education (3 ${ }^{\text {rd }}$ Edition.). New York: Columbia University Press.

2. Blaug, M. (1965). Rate of return on investment in education in Great Britain. Manchester School, 33 (3), 205-51.

3. Blaug, M. (1987). The economics of education and the education of an economist. Aldershot: Edward Elgar Publishing.

4. Clark, B. (1983). Creating entrepreneurial universities: Pathways to transformation. London: Oryx Press.

5. Buea University Newsletter, BUN. (2008). BMP at the University of Buea: One Year Later. Limbe: Presprint Plc., 11 (3).

6. Decree $N^{o}$. 93/026 of $19^{\text {th }}$ January 1993 creating state universities in Cameroon.

7. Decree $N^{\circ} .93 / 027$ of $19^{\text {th }}$ January 1993 providing common guidelines on the operations of the State Universities in Cameroon.

8. Decree $N^{\circ} .93 / 034$ of $19^{\text {th }}$ January 1993 organizing the University of Buea.

9. Decree of $27^{\text {th }}$ November 1992 creating the Cameroon Ministry of Higher Education.

10. Decree $N^{\circ} 92 / 074$ of $13^{\text {th }}$ April 1992 to transform the Buea and Ngoundere Centres into Universities.

11. De la Harpe, B, Radloff, A., Wyber, J. (2000). Quality and generic (professional) skills. Quality in Higher Education, 6 (3), 231-243.

12. Doh, P. (2012). The Responses of the Higher Education Sector in the Poverty Reduction Strategies in Africa: the Case of Cameroon. Doctoral Dissertation, Acta Universitatis Tamperensis 1755, Tampere University Press, Tampere. 
13. Cameroon Prime Ministry (2011). Celebration of the 45th Edition of the National Youth Day: Head Of State's Message. Retrieved from http://www.spm.gov. $\mathrm{cm} / \mathrm{en} /$ documentation/speeches/president-of-the-republic-speeches.html

14. Cloete, N., Maassen, P. (2002). "Global reform trends in higher Education". In Transformation in higher education, global pressures and local realities in South Africa, edited by Cloete Nico. Retrieved from at www.chet.org.za

15. Engell, J., Dangerfield, A. (1998). The market-model university: Humanities in the age of money. Harvard Magazine, 3, 48-55.

16. ESSP (2006) La strategie sectorielle de l'education (Education Sector Strategic Plan). Retrieved from http://planipolis.iiep.unesco.org/upload/ Cameroon/Cameroon_sectorstrategy.pdf

17. Geiger, R. (2004). Knowledge and money: Research universities and the paradox of the marketplace. Stanford: Stanford University Press.

18. GESP. Growth and Employment Strategy Paper (GESP) for 2010-2020. (2009). Cameroon: Government of Cameroon.

19. Gumport, P. (2002). Universities and knowledge: Restructuring the city of intellect. In The future of the city of intellect: The changing American university, edited by Steven Brint. Stanford: Stanford University Press.

20. Hartog, J. (2000). Over-education and earnings: where are we, where should we go? Economics of Education Review, 19, 131-147.

21. Hillage, J., Pollard, E. (1998). Employability: developing a framework for policy analysis. Research Brief 85, Department for Education and Employment.

22. Kirp, D. (2003). Shakespeare, Einstein, and the bottom line: The marketing of higher education. Cambridge, MA: Harvard University Press.

23. Kivinen, O., Nurmi, J. (2014). Labour market relevance of European university education. From enrolment to professional employment in 12 countries. European Journal of Education, 49 (4), 558-574.

24. Knight, P. (2001). Employability and assessment. Skills plus - a paper prepared for the fourth colloquium.

25. Knight, P., Yorke, M. (2000). Skills plus: Tuning the Undergraduate Curriculum. Skills Plus Project Report.

26. Konings, P. (2002). University students' revolt, ethnic militia, and violence during political liberalization in Cameroon. African Studies Review, 45 (2), 179-204.

27. Law No. 005 of 16 April 2001 on the Orientation of Higher Education Retrieved from http://www.spm.gov.cm/fr/documentation/textes-legislatifset-reglementaires/article/loi-n-005-du-16-avril-2001-portant-orientation-delenseignement-superieur.html

28. Law No. 2005/342 of 10 September to 2005 modify and complete certain dispositions of Decree No. 93/027 of 19 January 1993 to define common conditions for the operation of Universities in Cameroon.

29. Leroux, J.-Y. (2014). The professionalization of degree courses in France: New issues in an old debate, Higher Education Management and Policy, 24(3), 87-105.

30. Marginson, S., Considine, M. (2000). The enterprise university: power, governance, and reinvention. Cambridge, England: Cambridge University Press.

31. Mbembe, A. (1985). Les Jeunes et l'ordre politique en Afrique noire. Paris: L'Harmattan.

32. MINESUP. Partnership Charter between University and the Industry. (2010). MINESUP: Yaounde.

33. MINESUP (2010) Sectoral Policy Document (For Higher Education) in Cameroon. Unpublished. Obtained in January 2012. 
34. Ndongko, T., Tambo, L. (2000). Educational Development in Cameroon, 1961-1999: Issues and Perspectives. Platteville: Nkemnji Global Tech.

35. Neave, G. (2002). The stakeholder perspective historically explored. Higher education in a globalising world. International trends and mutual observation. Dordrecht: Kluwer.

36. Ngwana, T. (2001). The implementation of the 1993 higher education reforms in Cameroon: Issues and Promises IN: Higher Education Policy: Institutions and globalisation. New dynamics in South Africa after 1994. Centre for Higher Education Transformation. South Africa. Retrieved from http://www.chet.org.za

37. Njeuma, D., Endeley, H., Mbuntum, F., Lyonga, N., Nkweteyim, D., Musenja, S., Ekanje, E. (1999). Reforming a national system of higher education: the case of Cameroon. Washington: ADEA-WGHE. Retrieved from http://www. adeanet.org/pubadea/publications/pdf/he_cameroon_en.pdf

38. Presidency of the Republic of Cameroon (2015) Head of State's Message to the Youth on the Occasion Of the 49th Edition of the National Youth Day. Retrieved from https://www.prc.cm/en/news/1155-head-of-state-s-message-on-theoccasion-of-the-49th-edition-of-the-national-youth-day

39. Presidency of the Republic of Cameroon (2014) Head of State's Message to the Youth on the Occasion Of the 48th Edition of the National Youth Day. Retrieved from https://www.prc.cm/en/multimedia/ documents/1174-head-of-state-message-to-the-youth-10-02-2014

40. Presidency of the Republic of Cameroon (2012) President Paul BIYA urges youths to work for economic emergence. Retrieved from https://www.prc.cm/en/ news/speeches-of-the-president/14-president-paul-biya-urges-youths-to-work-foreconomic-emergence

41. Reinert, E. (2007). How rich countries got rich and why poor countries stay poor. New York: Carroll and Graf Publishers.

42. Renaut, A. (1995). Les revolutions de l'universite: Essai sur la modernisation de la culture. Paris: Calmann-Levy.

43. Robbins, L. (1963). Higher Education. (Report of the Committee under the Chairmanship of Lord Robbins). Cmnd 2154 HMSO.

44. Samfoga, D. (2015). Evaluating the strategic objectives of Cameroonian higher education: An application of the balanced scorecard (Unpublished Doctoral Dissertation). Turku: University of Turku.

45. Schultz, T. (1961). Investment in human capital. American Economic Reviez, 51, 1-17.

46. Sup Infos (2011). Sup Infos: Edition Special 1961-2011. Les 50Ans de Luniversite Camerounaise, Yaounde: MINESUP.

47. Sup Infos (2011) Bilingual Monthly Review of the Ministry of Higher Education. Yaounde: MINESUP, 19.

48. Symes, C., McIntyre, J. (2000). Working knowledge: the new vocationalism and higher education. Philadelphia, Pa: Society for Research into Higher Education and Open University.

49. Tambo, L. (2003). Cameroon National Education Policy since the 1995 Forum. Limbe: Design House.

50. Up Station Mountain Club (2007). Youth Day Message by President Paul Biya. Retrieved from http://www.postnewsline.com/2007/02/youth_day_messa.html

51. Yorke, M. (2001). Employability in the first cycle higher education. A working paper for the "Skills Plus" Project. Liverpool, John Moores U. 